\title{
Solitary extramedullary plasmocytoma of the liver
}

\author{
Senada Husarić ${ }^{1}$, Jasmina Pašić ${ }^{1}$, Enisa Alić ${ }^{1}$, Maida Kuljanin ${ }^{2}$
}

${ }^{1}$ Department of Endocrinology, University Clinical Center Tuzla, Tuzla, Bosnia and Hercegovina ${ }^{2}$ Department of Pathology, University Clinical Center Tuzla, Tuzla, Bosnia and Herzegovina

Solitary extrameduallary plasmacytomas represent approximately $3 \%$ of all plasma cell neoplasms. Extramedullary plasmacytoma of the liver is a very rare tumor, although a few cases of extramedullary plasmacytoma of the liver have been reported. We report an unusual case of liver plasmacytoma without systemic disease, diagnosed by percutaneous needle biopsy of the hepatic lesion. The patient was a 67 year old female who exhibited a solitary liver mass on dynamic computed tomography (Panel A). We performed percutaneous needle biopsy of the hepatic lesion. Histologically, the tumor was composed of CD 138 positive plasma cells with mild atypia (Panel B: H\&Ex40 black arrow), and $80 \%$ of them demonstrated Kappa light chain (Panel C: H\&Ex40 red circle - white arrow). There was no evidence of a monoclonal protein in the serum and urine, lytic bone lesions, anemia, renal insufficiency, or hypercalcemia. The bone marrow examination revealed no abnormalities. The patient was treated with local radiation and is doing well without further evidence of disease after one year of follow-up. Primary extramedullary plasmacytoma (EMP) is defined as an extraosseous proliferation of neoplastic plasma cells, without evidence of bone or
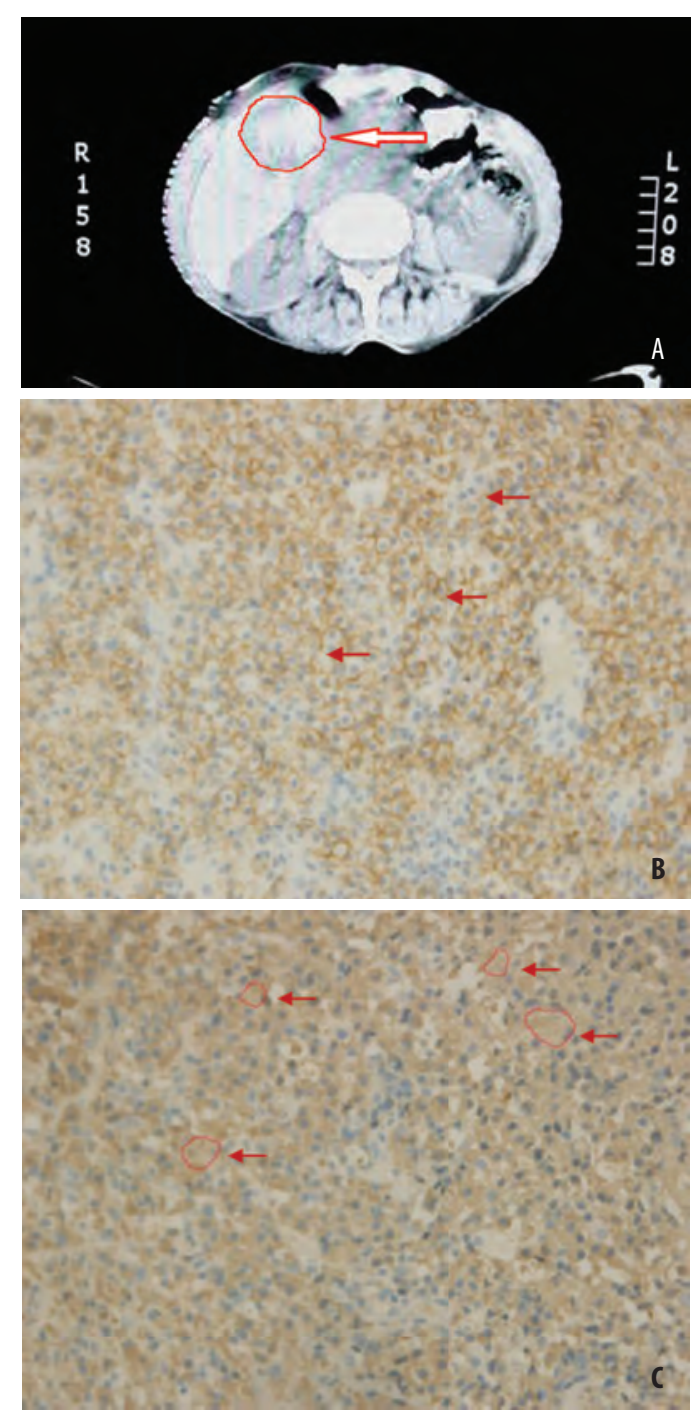

bone marrow involvement, as evidenced by morphological bone marrow examination and radiographic studies. EMP accounts for 
about $3 \%$ of plasma cell tumors, and more than $80 \%$ occur in the upper aerodigestive tract. Among the plasmacell dyscrasias, a rare form is the extramedullary plasmacytoma requiring, for diagnosis, histological evidence of monoclonal plasmacell infiltration localized in the lesion, in the absence of a marrow plasmacytosis. This peculiar presentation of a plasmacell neoplasia is rarely observed in the liver, while it is most frequently seen in the mucosa of the upper airway. Generally, the presence of plasmacells in the liver, spleen and lymphonodes, is associated with a more aggressive form of multiple myeloma (1). The diagnosis of solitary extramedullary plasmacytoma requires the demonstration of a monoclonal plasma cell infiltrate without any evidence of multiple myeloma elsewhere. Only a few cases of primary hepatic extramedually plasmacytoma have been reported (2). The patient described here is a woman who presented with a solitary hepatic extramedullary plasmacytoma without evidence of myeloma elsewhere, including no monoclonal protein in the serum or urine.

Key words: Plasmocitoma, Extramedullare, Liver.
Authors' contributions: Conception and design: SH; Acquisition, analysis and interpretation of data's: $\mathrm{SH}$ and JP; Drafting the article: EA and MK; Revising it critically for important intellectual content: $\mathrm{SH}$ and $\mathrm{MK}$.

Conflict of interest: The authors declare that they have no conflict of interest.

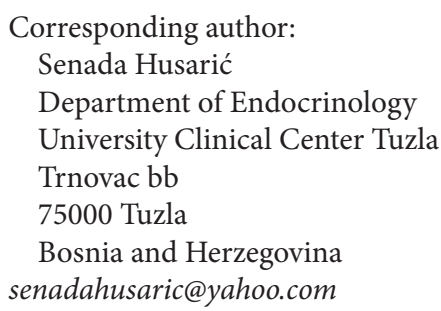

Copyright (C) 2013 by Academy of Sciences and Arts of Bosnia and Herzegovina. E-mail for permission to publish:amabih@anubih.ba

\section{References}

1. Petrucci MT, Tirindelli MC, De Muro M, Martini V, Levi A, Mandelli F. Extramedullary liver plasmacytoma a rare presentation. Leuk Lymphoma. 2003;44(6):1075-6.

2. El Maaroufi H, Doghmi K, Rharrassi I, Mikdamea M. Extramedullary plasmacytoma of the liver. Hematol Oncol Stem Cell Ther. 2012;5(3):172-3. 